Génét. Sél. Evol., 1988, 20 (1), 99-104

\title{
Note
}

\section{Haemoglobin type frequencies in the Assaf (Awassi $\times$ East Friesian) dairy sheep 20 years after its formation}

\author{
E. GOOTWINE \\ Institute of Animal Science, Agricultural Research Organization, \\ Bet Dagan, Israel
}

\begin{abstract}
Summary
Haemoglobin allele frequencies were examined in 195 ewes and 6 rams belonging to the Assaf cross (Awassi $\times$ East Friesian). The frequency of the $H b A$ allele was 0.14 indicating a decline in $H b A$ frequency in the Assaf during the last 20 years. Ewes belonging to the $A B$ genotype showed a significant advantage over the $B B$ genotype in both lamb and milk production in the first lactation. It is suggested that the haemoglobin polymorphism in the Assaf is maintained due to an advantage of $A B$ heterozygotes for production and survival.
\end{abstract}

Key words : sheep, haemoglobin, Assaf breed, milk production, lamb production.

\section{Résumé}

Fréquences des types d'hémoglobine dans la race ovine laitière Assaf (Awassi $\times$ Frisonne de l'Est) 20 ans après sa création

Les fréquences des allèles hémoglobine ont été étudiées chez 195 brebis et six béliers de la race Assaf (Awassi $\times$ Frisonne de l'Est). La fréquence de l'allèle $H b A$ est de 0,14 , indiquant une diminution de la fréquence de cet allèle chez les Assaf au cours des 20 dernières années. Les brebis de génotype $A B$ possèdent une supériorité significative sur celles de génotype $B B, \operatorname{tant}$ pour la production d'agneaux que pour la production laitière en première lactation. Il est suggéré que le polymorphisme de l'hémoglobine est maintenu dans la race Assaf grâce à un avantage des hétérozygotes $A B$ pour les caractères de production et de viabilité.

Mots clés : ovin, hémoglobine, race Assaf, production laitière, production d'agneaux.

\section{Introduction}

Two main electrophoretic types of sheep haemoglobin (Hb), designated $A$ and $B$, have been described (HARRIS \& WARREN, 1955). These types, which were shown to be 
determined by two alleles at a single locus (Evans et al, 1956), give rise to three genotypes : $A A, A B$ and $B B$. Allele frequencies of $\mathrm{Hb}$ types vary among breeds of sheep (see review by AGAR et al., 1972). Following the observation that flocks in which $\mathrm{Hb} \mathrm{A}$ is predominant are confined to latitudes above $40^{\circ}$, the theory was advanced that $\mathrm{Hb}$ polymorphism may have adaptive significance. The study of Evans \& BLunT (1961), showing that movement of a breed away from its place of origin appears to have an effect on the $\mathrm{Hb}$ allele frequencies, supports this idea.

Adaptation to the environment is of great importance in determining animal performance. In line with this, the relationship between $\mathrm{Hb}$ types and productive and reproductive traits has been examined by a number of authors (AgAR et al., 1972; Templeton et al., 1972 ; Pant \& Pandey, 1975 ; Gootwine \& Goot, 1979 ; Dally et al., 1980).

The allele $A$ frequency in the fat-tail Awassi sheep in Israel is very low - less than $2 \%$ (Evans et al., 1958). The prolificacy of the breed is rather low $(1.2 \mathrm{lambs} /$ ewe/lambing) and in order to increase lamb production in dairy flocks, crossbreeding between the Awassi and the East Friesian breeds was carried out in the 1960's (Goot, 1966 ; Eyal et al., 1978), resulting in the formation of the synthetic Assaf breed. At present, most of the dairy ewes in Israel (approximately 8000 head) are of the Assaf breed. The frequency of the $H b A$ allele in the $\mathrm{F}_{1}$ of the cross was found to be 0.38 , a value intermediate between the frequencies in the parental breeds (RESHEF, 1965). However, with time, the frequency of allele $A$ was reduced, and reached 0.22 in the $\mathrm{F}_{3}$. In another study (EYAL, 1968), it was found that Assaf ewes belonging to the $B B$ genotype produce more lambs and have a longer life span than ewes with the $A B$ genotype. On the other hand, ewes with the $A B$ genotype were found to produce more milk.

During the last 20 years the Assaf population has been subjected to both artificial (milk and lamb production) and natural selection. The objective of this study was to examine present $\mathrm{Hb}$ allele frequencies in the Assaf in relation to their possible adaptive value.

\section{Material and methods}

The study was conducted in the Newe Ya'ar Assaf dairy flock in which an $\mathrm{Hb}$ survey had been carried out approximately 20 years ago (RESHEF, 1965). All the sheep present in the flock at the time of the survey (195 one to eight years old ewes and 6 two to five years old rams) were examined for their $\mathrm{Hb}$ type. Haemoglobin types were determined by vertical starch gel electrophoresis (SMITHIES, 1955), using borate buffer (gel, $\mathrm{pH}$ 8.6).

Sheep are kept indoors under intensive management throughout the year, as described previously (EYAL et al., 1978). Selection for replacement is done using an index in which milk and lamb production are both included and one lamb is considered to be economically equal to 230 litres of milk. Ewe lambs for replacement are obtained from the flock while rams are often brought from commercial flocks. In this flock, the rate of ram replacement is high and on the average five new rams are introduced each year. 
Milk yield (as defined by Morag et al., 1973) was recorded monthly, and in order to arrive at lactation, or annual milk production, the sum of these records was multiplied by 30 .

To compare $\mathrm{Hb}$ genotypes for milk and lamb production during their first, second and third lactations, least squares analysis of variance by the SAS-GLM procedure was applied. In this analysis, records from all the 21 two to four years old $A B$ ewes and records from 82 of the 90 two to four years old $B B$ ewes were analysed. Data from two years old ewes included information about the first lactation only, while data from four years old ewes included information about three successive lactations. Sources of variation in the analysis were $\mathrm{Hb}$ genotype, year and lactation number.

\section{Results}

The distribution of $\mathrm{Hb}$ types and their allelic frequencies in the Newe Ya'ar Assaf dairy flock are shown in table 1 . The $H b A$ frequency in the 195 females was 0.14 and in the six males was 0.25 , giving an overall frequency of 0.14 for allele $A$. No significant differences were found between allele frequencies in the different age groups. Chi-square analysis of the ewe population shows that the genotype distribution does not deviate significantly from Hardy-Weinberg equilibrium, $\left(P\left(\chi^{2}{ }_{5}<2.8\right)=0.24\right)$.

TABLE 1

Distribution of haemoglobin $(\mathrm{Hb})$ genotypes and $\mathrm{Hb} \mathrm{A}$ allele frequencies $\left(P_{A}\right)$ in ewes and rams of the Newe Ya'ar Assaf dairy flocks

\begin{tabular}{|c|c|c|c|c|c|c|}
\hline \multirow{2}{*}{ Sex } & \multirow{2}{*}{$\underset{\text { (years) }^{\text {Age }}}{*}$} & \multirow{2}{*}{$\mathrm{n}$} & \multicolumn{4}{|c|}{ Hb genotype } \\
\hline & & & $A A$ & $A B$ & $B B$ & $P_{A}$ \\
\hline \multirow[t]{6}{*}{ Ewes } & 1 & 29 & 1 & 7 & 21 & 0.15 \\
\hline & 2 & 33 & 2 & 6 & 25 & 0.15 \\
\hline & 3 & 34 & 1 & 6 & 27 & 0.15 \\
\hline & 4 & 47 & - & 9 & 38 & 0.10 \\
\hline & $5-6$ & 40 & 2 & 10 & 28 & 0.17 \\
\hline & $7-8$ & 12 & 1 & 4 & 7 & 0.21 \\
\hline $\begin{array}{l}\text { Ewes } \\
\text { Total }\end{array}$ & $1-8$ & 195 & 7 & 42 & 146 & 0.14 \\
\hline Rams & $2-5$ & 6 & - & 3 & 3 & 0.25 \\
\hline
\end{tabular}

* Age at time of $\mathrm{Hb}$ survey.

Milk and lamb production in the first, the second and the third lactation were compared between ewes 2, 3 and 4 years old from the $A B$ and $B B \mathrm{Hb}$ genotypes (Table 2). Significant differences were found in favour of the $A B$ genotype in the first 
TABLE 2

Least squares means of lambs born per ewe per lambing $(L / E / L)$ and milk yield in the first, second and third lactation of Assaf ewes belonging to $\mathrm{Hb} A B$ and $\mathrm{Hb} B B$ genotypes

\begin{tabular}{l|c|c|c|c}
\hline \hline \multicolumn{1}{c|}{ Lambing } & Hb genotype & $\mathrm{n}$ & L/E/L & $\begin{array}{c}\text { Milk yield/ } \\
\text { year }(\mathrm{kg})\end{array}$ \\
\hline \multirow{3}{*}{ First } & $A B$ & 21 & $1.56^{\mathrm{A}}$ & $266^{\mathrm{A}}$ \\
\multirow{3}{*}{ Second } & $B B$ & 82 & $1.27^{\mathrm{B}}$ & $210^{\mathrm{B}}$ \\
& $A B$ & 15 & 1.73 & 300 \\
Third & $B B$ & 65 & 1.53 & 263 \\
& $A B$ & 9 & 1.66 & 261 \\
& $B B$ & 34 & 1.71 & 264 \\
\hline
\end{tabular}

Mean in the same square with different superscripts are significantly different $(P<0.05)$.

lactation both in lambing percentage $(P<0.03)$ and in milk production $(P<0.01)$. An advantage of the $A B$ genotype was evident also in the second lactation ; however, here the differences were not statistically significant. In the third lactation milk production and lambing percentage were found to be similar in the two genotypes.

In a small flock all the individuals carrying the rare allele can be the offspring of a common father. In this case deviation from the population mean of this group in performance can be the outcome of sire rather than genotype effect. Pedigree analysis of the flock shows that in the present study, the $21 A B$ ewes which participated in the analysis are daughters of eight rams.

\section{Discussion}

Three lines of evidence : (i) the very low frequency of $H b A$ allele in the local Awassi breed (Evans et al., 1958) ; (ii) the inferior survival ability of Assaf and pure East Friesian ewes carrying $H b A$ in comparison with homozygous $B B$ ewes (RESHEF, 1965 ; EYAL, 1968) ; and (iii) the repeated decline in $H b A$ frequency from 0.38 in the $\mathrm{F}_{1}$ to 0.22 in the $\mathrm{F}_{3}$ led to the assumption that $H b A$ frequency will continue to decline, with time, in the Assaf population in Israel.

In the present study, which was done some eight generations after the Hb survey in the $\mathrm{F}_{3}$, the $\mathrm{Hb} \mathrm{A}$ allele frequency calculated was 0.14 indicating a further decline in the allele $A$ frequency. This change in the $\mathrm{Hb}$ allele frequency may be due to drift effect. However, the possibility that selection forces are involved, have to be taken into consideration. The further decline in the Assaf breed, of the $A$ allele which originated almost entirely from the East Friesian parental breed, can be explained by the apparently shorter life span of the $A$ allele carriers (RESHEF, 1965 ; Eyal, 1968). Yet it is evident that the rate of the decline in the later generations was lower than in the first generations. 
On the other hand, the $A B$ genotype showed in this study a significant advantage over the $B B$ genotype both in lamb and milk production in the first lactation and possibly also in the second one. A similar advantage in milk production was noted in previous work (RESHEF, 1965 ; EYAL, 1968). Since in the Assaf dairy flocks selection for high milk and lamb production is done usually on the mean production over three or more lactations, carrying the $A$ allele has economic selective advantages. The present allele $A$ frequency in the population, therefore, may be the outcome of the advantage of the $A B$ heterozygotes on $A A$ homozygotes for survival and on $B B$ homozygotes for production. Hence, the $A B$ genotype could serve as an indirect selection criterion for milk and lamb production in the Assaf breed.

Received June 24, 1985.

Accepted July 1, 1987.

\section{Acknowledgements}

I would like to thank Dr. A. Genizi for his help in the statistical analysis and Mr. A. Zenou for his help in record keeping. This research was supported by the Agricultural Research Organization, the Volcani Center, Bet Dagan, Israël (contribution No. 1453-E, 1985 series).

\section{References}

Agar N.S., Evans J.V., Roberts J., 1972. Red blood cell potassium and haemoglobin polymorphism in sheep. A review. Anim. Breed. Abstr., 40, 407-436.

Dally M.R., Hohenboken W., Thomas D.L., Craig M., 1980. Relationships between haemoglobin type and reproduction, lambs, wool, and milk production and health-related traits in crossbred ewes. J. Anim. Sci., 50, 418-427.

Evans J.V., Blunt M.H., 1961. Variation in the gene frequencies of potassium and haemoglobin types in Romney Marsh and Southdown sheep established away from their native environment. Aust. J. Biol. Sci., 14, 100-108.

Evans J.V., King W.B., Cohen B.L., Harris H., Warren F.L., 1956. Genetics of haemoglobin and blood potassium differences in sheep. Nature (Lond.), 178, 849-850.

Evans J.V., Harris H., Warren F.L., 1958. Haemoglobin and potassium blood types in some non-British breeds of sheep and in certain rare British breeds. Nature (Lond.), 182, 320-321.

EyAL E., 1968. Haemoglobin typing - a possible trend in selection of sheep for environment adaptability (in Hebrew). HaNoked, 68, 22-27.

Eyal E., Lawi A., Folman Y., Morag M., 1978. Lamb and milk production of a flock of dairy ewes under an accelerated breeding regime. J. Agric. Sci. (Camb.), 91, 69-79.

Goot H., 1966. Studies on the native Awassi sheep and its crosses with the exotic East Friesian milk sheep (in Hebrew, with English summary). Pam. Nat. Univ. Inst. Agric., Rehovot, $N^{\circ} 115$.

Gootwine E., Goot H., 1979. Relationship between haemoglobin types and some production traits in Finnish crosses of sheep in Israel. Spec. Publ. Agric. Res. Organ., Bet Dagan $N^{o} 132$.

HARRIS H., WARREN F., 1955. Occurrence of electrophoretically distinct haemoglobin in ruminants. Biochem. J., 60, 29-33. 
Morag M., Sagi R., Eyal E., Folman Y., 1973. The definition of milk yield and milk fractions in lactating animals. J. Agric. Sci. (Camb.), 81, 361-363.

Pant H.C., Pandey M.D., 1975. Influence of haemoglobin type on the induced ovulation rate in sheep. Nature, 256, 738-739.

RESHEF I., 1965. Haemoglobin types frequency in sheep breeds in Israel and its relation to several traits (in Hebrew). M.Sc. thesis. The Hebrew University of Jerusalem, Rehovot, Israel.

Smithies O., 1955. Zone electrophoresis in starch gels : group variation in the serum proteins of normal human adults. Biochem. J., 61, 629-641.

Templeton J., Price D., Bogart R., 1972. Frequency of haemoglobin types in five breeds of sheep. J. Hered., 63, 202-204. 